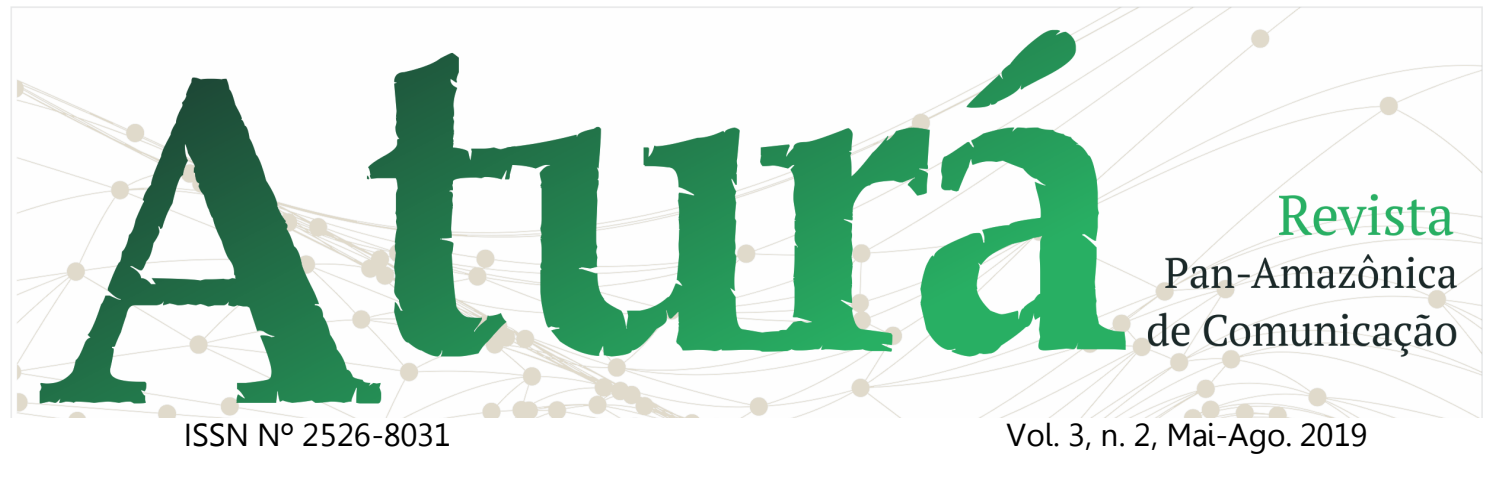

\title{
NEGROS EM FOCO: uma análise de matérias jornalísticas sobre a marca Lab no SPFW
}

Black in focus: an analysis of journalistic articles about the fashion label LAB at SPFW

Negros en foco: un análisis de artículos periodísticos sobre la marca LAB en SPFW

\author{
Jaine Araújo da Silva ${ }^{1}$ \\ Francielle Maria Modesto Mendes²
}

\section{RESUMO}

Este trabalho resulta de uma pesquisa monográfica sobre a temática racial negra brasileira tendo como objeto 23 matérias jornalísticas acerca da grife LAB. Visa-se compreender as representações construídas sobre o negro na marca, que em seus desfiles no São Paulo Fashion Week levou às passarelas $90 \%$ de modelos negros. Para isso, é feita a análise do conteúdo de matérias dos sites Elle, Vogue, Estadão e Folha de São Paulo. Ao fim da pesquisa, concluiu-se que, embora os negros tenham sido exaltados nas matérias analisadas, o racismo continua existindo no Brasil. Os principais conceitos trabalhados são: raça, racismo, representação, empoderamento e lugar de fala, com base em Schwarcz (2012), Almeida (2018), Hall (2016), Berth (2018), Ribeiro (2017) etc.

PALAVRAS-CHAVE: LAB; Moda; Negros; Racismo; Representação.

\footnotetext{
${ }^{1}$ Graduanda do $8^{\circ}$ período do curso de Comunicação Social/Jornalismo da Universidade Federal do Acre (UFAC). Email: araujojaine7@gmail.com.

2 É doutora em História Social pela Universidade de São Paulo (USP) e professora do curso de Jornalismo e do Programa de Pós-Graduação em Letras: Linguagem e Identidade, na Universidade Federal do Acre (UFAC). Email: franciellemodesto@gmail.com.
} 


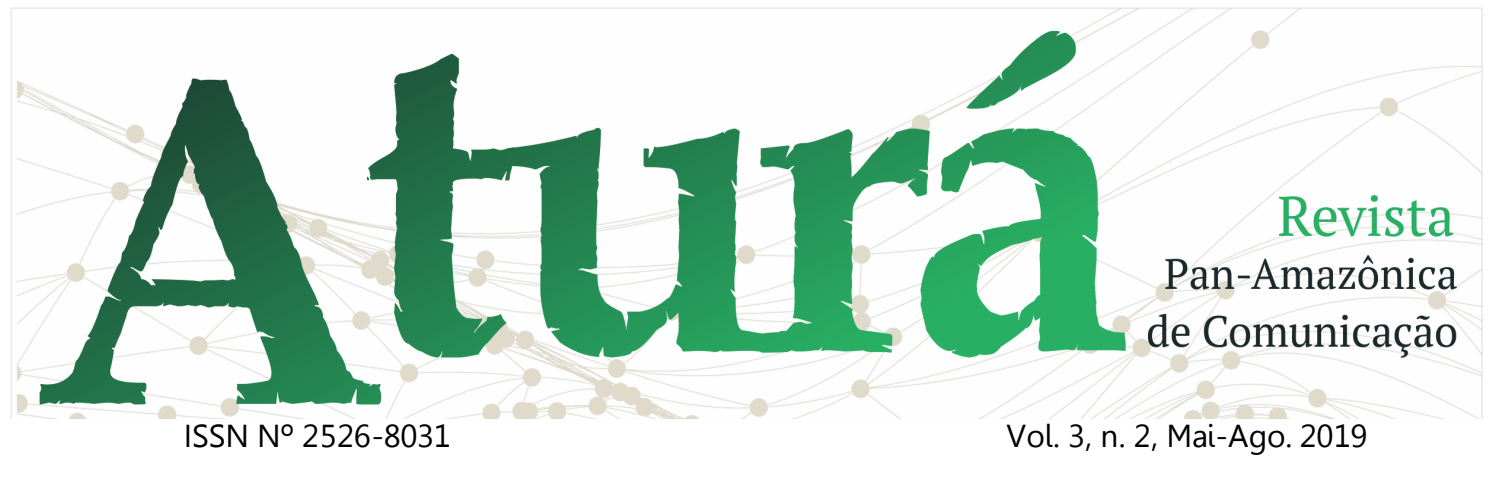

\begin{abstract}
This paper is the result of a research on the brazilian black racial theme. Twenty-three journalistic articles about the fashion brand LAB were analyze. The goal was to understand the representations built around the black models, since $90 \%$ of the models taken to the runway by this brand at Sao Paulo Fashion Week were black. For this, a content analysis of the journalistic articles published by the Elle, Vogue, Estadão and Folha de São Paulo websites was performed. At the end of the research, it was concluded that although blacks were exalted in the analyzed articles, racism still exists in Brazil. The main concepts studied here are: race, racism, representation, empowerment and place of speech, based on Schwarcz (2012), Almeida (2018), Hall (2016), Berth (2018), Ribeiro (2017) etc.
\end{abstract}

KEYWORDS: LAB; Fashion; Black; Racism; Representation.

\title{
RESUMEN
}

Este trabajo es el resultado de una investigación monográfica sobre el tema racial negro brasileño basada en 23 artículos periodísticos sobre la marca LAB. Pretende comprender las representaciones construidas acerca de el negro en la marca, que en sus desfiles en São Paulo Fahion Week llevó a las pasarelas $90 \%$ de modelos negros. Para ello, se realiza el análisis de contenido de los sitios web de Elle, Vogue, Estadão y Folha de São Paulo. Al final de la investigación, se concluyó que aunque los negros han sido exaltados en los textos analizados, el racismo aún existe en Brasil. Los principales conceptos estudiados son: raza, racismo, representación, empoderamiento y lugar de expresión, basados en Schwarcz (2012), Almeida (2018), Hall (2016), Berth (2018), Ribeiro (2017), entre otros.

PALABRAS CLAVE: LAB; Moda; Negros; Racismo; Representación.

Recebido em: 24.02.2019. Aceito em: 24.04.2019. Publicado em: 01.05.2019. 


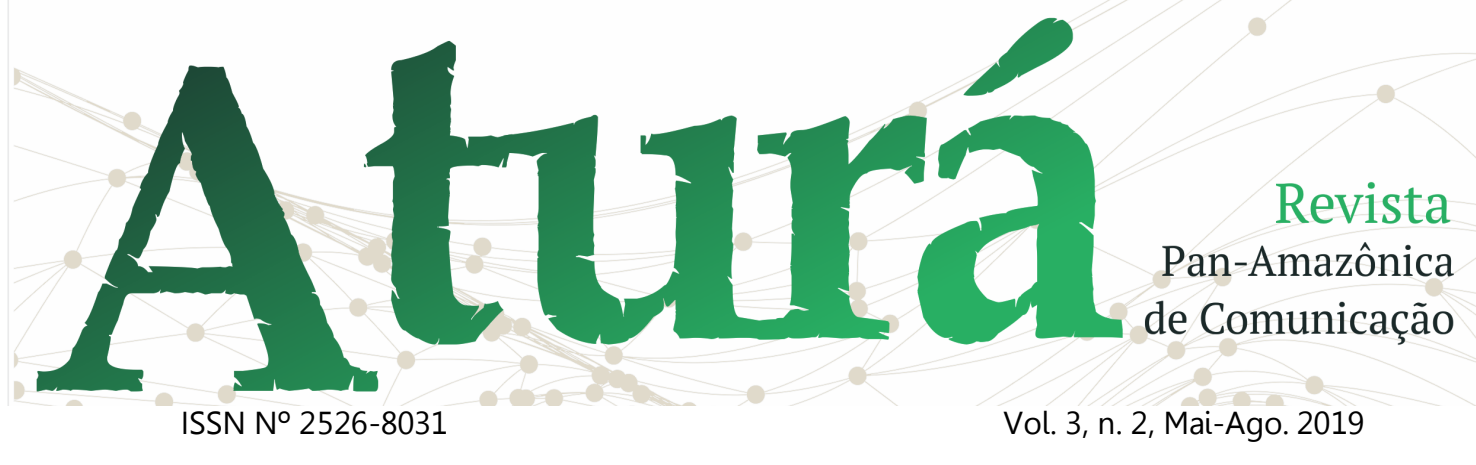

\section{Introdução}

Este artigo é resultado de uma pesquisa monográfica que tem como foco a participação da $L A B$, oficializada como grife em 2016, nos desfiles da 42a, $43^{a}$ e $44^{a}$ edição do São Paulo Fashion Week (SPFW).

A LAB pertence aos irmãos músicos Leandro de Oliveira, Emicida, e Evandro de Oliveira, Fióti. A grife surgiu a partir do selo de música independente Laboratório Fantasma; 90\% do seu casting (seleção de modelos) é de negros, algo incomum no mundo fashion, mesmo em eventos de moda realizados no Brasil, composto majoritariamente por pretos e pardos. De acordo com o Censo Demográfico (2010), divulgado pelo Instituto Brasileiro de Geografia e Estatística (IBGE), pretos e pardos somam 50,9\% da população brasileira - 97.171.614 pessoas. Segundo o estudo, pretos representam $7,5 \%$ da população, enquanto pardos, $43,4 \%$.

A problemática desta pesquisa é: quais as representações forjadas pelos veículos Folha de São Paulo, Estadão, Elle e Vogue sobre a figura do negro nos desfiles da marca $L A B$ na última edição da SPFW de 2016 e nas duas edições do evento em 2017?

O objetivo geral do trabalho é analisar 23 matérias dos sites dos referidos veículos, buscando entender as representações construídas sobre os negros que desfilaram para a grife. As matérias foram coletadas em outubro de 2016 e nos meses de março e agosto de 2017, período próximo à realização do São Paulo Fashion Week.

Os textos analisados foram divididos em dois grupos temáticos: o primeiro refere-se à participação da grife no SPFW; já o segundo, ao episódio de racismo vivido por um dos donos da marca ao final do último desfile. Os textos do primeiro grupo mostram que a presença de uma grife com casting majoritariamente negro é vista como uma iniciativa inovadora e representativa da população brasileira, enquanto o segundo grupo temático mostra que o racismo é um problema atual no Brasil, inclusive na moda.

A pesquisa se justifica a partir da necessidade de compreender como o racismo impacta a vida dos negros, seja na exclusão, seja na construção de representações que fortalecem um imaginário que também exclui e marginaliza este grupo. Apesar de pretos e pardos somarem mais da metade da população brasileira - 55,5\% da população de acordo com a última Pesquisa Nacional por Amostra de Domicílios Contínua (PNADC) - a presença dessa parcela da sociedade em espaços de grande visibilidade e positividade é insignificante, se 


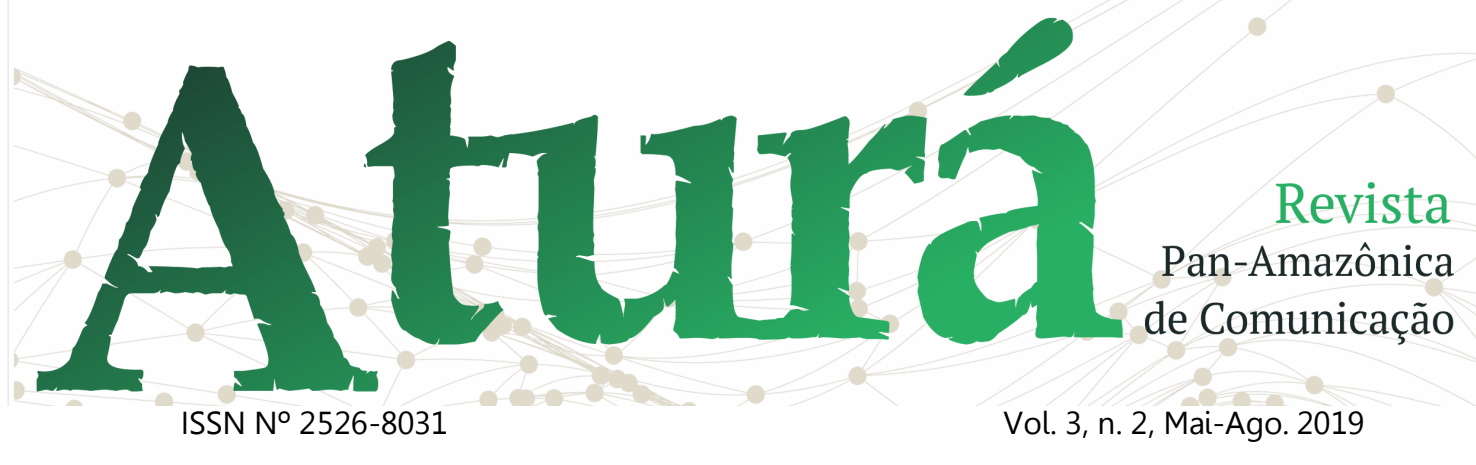

comparada à presença dos brancos. Neste sentido, entende-se que o SPFW é apenas mais um espaço padronizado tendo o branco como figura única.

No que tange à metodologia, optou-se por um levantamento bibliográfico sobre 0 termo "representação". Para o estudo dos textos jornalísticos, fez-se uma Análise de Conteúdo, que consiste em "um conjunto de técnicas de análise das comunicações" (BARDIN, 1977: p.31). O método possui duas funções: a heurística, pois "enriquece a tentativa exploratória, aumenta a propensão à descoberta" (BARDIN, 1977: p.30); e a de administração da prova, na qual hipóteses em forma de questões ou afirmações provisórias servem como diretrizes e são verificadas buscando confirmação ou anulação (BARDIN, 1977). Para a autora, a primeira função serve para aprofundar uma pesquisa, enquanto a segunda torna a análise uma prova.

A corrente teórica usada é a dos Estudos Culturais, considerando-se a relevância da cultura enquanto terreno de lutas e mudanças sociais (KELLNER, 2009). Em suma, esta corrente permite que uma maior gama de manifestações culturais seja objeto de estudo e, consequentemente, ajude na compreensão de determinada realidade social, histórica e cultural.

\section{A questão racial no Brasil}

De acordo com Schwarcz (2012), o tema "raça" nunca foi neutro no Brasil, pois, as teorias deterministas raciais datam do século XVIII, mas antes disso o termo "raça", criado no século XVI, significava "'grupos ou categorias de pessoas conectadas por uma origem comum'" (SCHWARCZ, 2012: p.20), ou seja, não se referia necessariamente a uma ordem natural. Mesmo adotando essa visão sobre o termo, muitos autores insistiam na busca pela naturalização das diferenças, fazendo de questões políticas e históricas dados inquestionáveis e, assim, construindo a noção de inferioridade dos negros (SCHWARCZ, 2012). Desta forma, entende-se o termo "raça" como uma construção histórica e social que abarca a questão cultural, e é considerado por Schwarcz (2012) como um marcador social de diferença:

Raça é, pois, uma categoria classificatória que deve ser compreendida como uma construção local, histórica e cultural, que tanto pertence à ordem das representações sociais - assim como o são fantasias, mitos e ideologias - como exerce influência real no mundo, por meio da produção e reprodução de identidades coletivas e de hierarquias sociais politicamente poderosas (SCHWARCZ, 2012: p.34).

Assim, compreende-se que a raça pode ser utilizada como instrumento para construção e fortalecimento do preconceito. Para Almeida (2018), raça é um termo relacional, histórico e, portanto, 


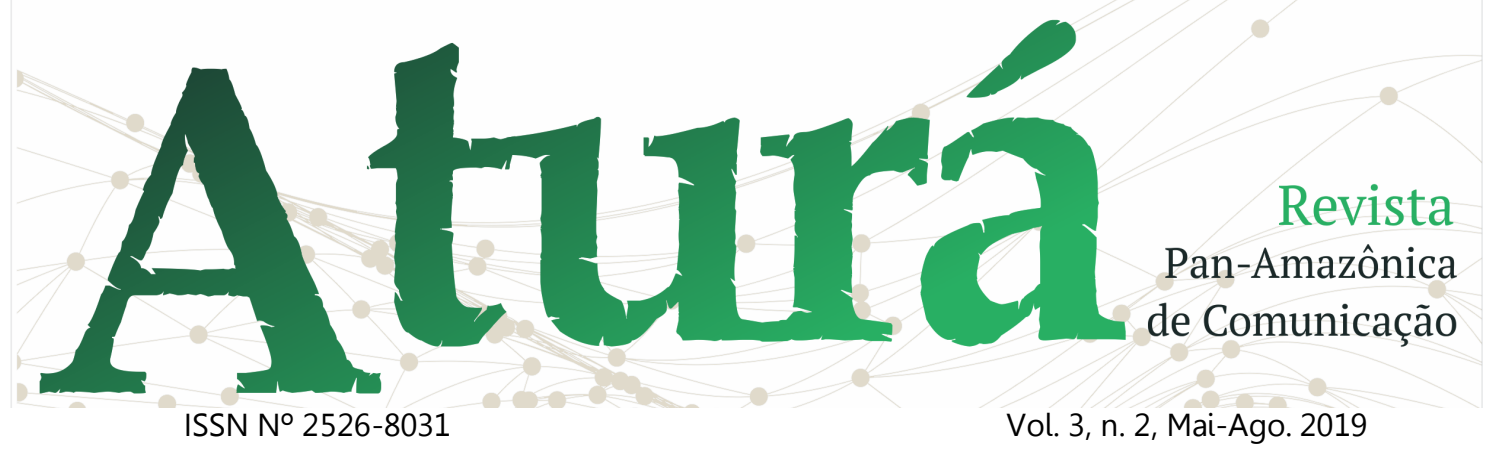

não fixo, sofrendo variações dependendo do local onde é utilizado e dos processos históricos vividos por tal sociedade.

Para o autor, o racismo molda tanto a consciência como o inconsciente, de modo que,

A vida cultural e política no interior da qual os indivíduos se reconhecem enquanto sujeitos autoconscientes e onde formam os seus afetos é constituída por padrões de clivagem racial inseridas no imaginário e em práticas sociais cotidianas (ALMEIDA, 2018: p.50).

Dito de outra forma, o racismo se manifesta da esfera coletiva para a individual, construindo um imaginário social, uma ideologia sobre a inferioridade do negro.

$\mathrm{Na}$ escala da hierarquização racial, o branco aparece como mais apto a dirigir os outros. A pessoa negra é considerada

[...] mais estúpida, mais emocional, menos honesta, menos inteligente e, portanto, a mais sujeita à escravidão e a todas as formas de dominação (MUNANGA, 2003: p.5).

Neste sentido, de acordo com o autor, cientistas antirracistas compreendem o conceito de raça como "uma construção sociológica e uma categoria social de dominação e de exclusão" (MUNANGA, 2003, p.6).

O racismo brasileiro possui características peculiares, se mostra nas entranhas da sociedade e da cultura, marcado por uma forte naturalização do lugar do branco e do lugar do negro. Schwarcz (2012) considera que o racismo é uma prática atribuída ao "outro", além de ser considerado brando, provocando uma sensação de existência da "harmonia racial" (SCHWARCZ, 2012: p.30). Dessa forma, ao invés de se buscarem alternativas para tratar o problema, ele é ignorado no Brasil.

Esse "racismo à la brasileira" (SCHWARCZ, 2012: p.34) foi constituído desde $\mathrm{o}$ processo de miscigenação. Apesar de a ideia do paraíso das três raças ainda ser defendida de forma romantizada, sabe-se que esse processo foi marcado por violência e objetivava embranquecer a população, alcançando um suposto avanço - seguindo as ideias evolucionistas que colocavam 0 negro enquanto sujeito primitivo, de modo que - branqueamento da escala de cores simbolizava a evolução:

Quanto mais branco melhor, quanto mais claro mais superior [...] se vê no branco não só uma cor, mas também uma qualidade social: aquele que sabe ler, que é mais educado e que ocupa uma posição social mais elevada (SCHWARCZ, 2012: p.44).

Esse embranquecimento também se dá num sentido figurado à medida que certas condições são capazes de tornar um indivíduo mais ou menos branco. Se uma pessoa tem pele escura, mas tem nível superior, isso a torna mais branca. 


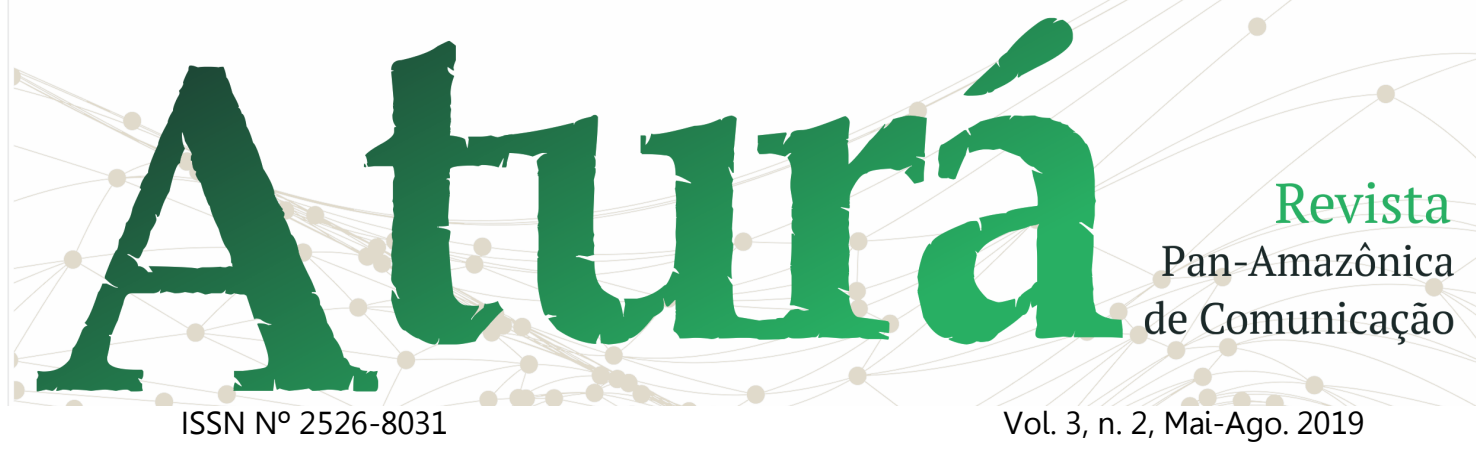

Ela enriquece, conquista fama, sucesso e destaque social.

\section{Representação, linguagem e produção de sentidos}

De acordo com Hall (2016), a representação permite a produção de significados por meio da linguagem. De modo que conceitos e linguagem se relacionam, possibilitando a referência

[...] ao mundo 'real' dos objetos, sujeitos ou acontecimentos, ou ao mundo imaginário de objetos, sujeitos e acontecimentos fictícios (HALL, 2016: p.34).

Essa afirmativa demonstra que este é um processo que permeia todas as relações e produções humanas, a forma como se percebe o mundo e, sobretudo, se interpreta tudo aquilo que é produzido pelo homem, seja no campo material, seja no simbólico.

A linguagem é onde as representações existem e recebem atribuições de sentidos (HALL, 2016). Ela permite que haja diálogo entre diferentes pessoas e faz com que estas compartilhem sentidos e interpretem o mundo de maneira semelhante, pois "opera como um sistema representacional" (HALL, 2016: p.18). Por meio da linguagem é possível representar sentimentos, ideias e pensamentos. Mas para que haja compreensão parecida ou igual por parte de diferentes sujeitos é necessário que estes tenham o mesmo

mapa conceitual, ou seja, partilhem da mesma cultura, entendendo o mundo de modo parecido, atribuindo aos signos os mesmos sentidos.

Silva (2012) explica que tanto identidade quanto diferença são produzidas social e culturalmente, fabricadas em contextos específicos, frutos de criação linguística. Em outros termos, é também no campo da linguagem que as identidades $e$ as diferenças são forjadas e onde podem ser modificadas, desconstruídas e reconstruídas de inúmeras formas.

Os signos estão dentro das linguagens e são

[...] palavras, sons ou imagens que carregam sentido. Eles indicam ou representam os conceitos e as relações entre eles que carregamos em nossa mente e que, juntos, constroem os sistemas de significados da nossa cultura (HALL, 2016: p. 37).

Neste trabalho foram analisados textos, ou seja, o signo estudado é a palavra - signo indexical, aquele que não se parece com o objeto ao qual se refere. Sua relação com esse objeto é arbitrária, já que cada idioma usa um conjunto de letras diferentes para se referir a uma árvore, por exemplo (HALL, 2016). Assim, compreende-se que as palavras podem ser usadas para construir representações bem específicas e variadas sobre quaisquer sujeitos ou objetos, a depender dos objetivos pretendidos por quem as 


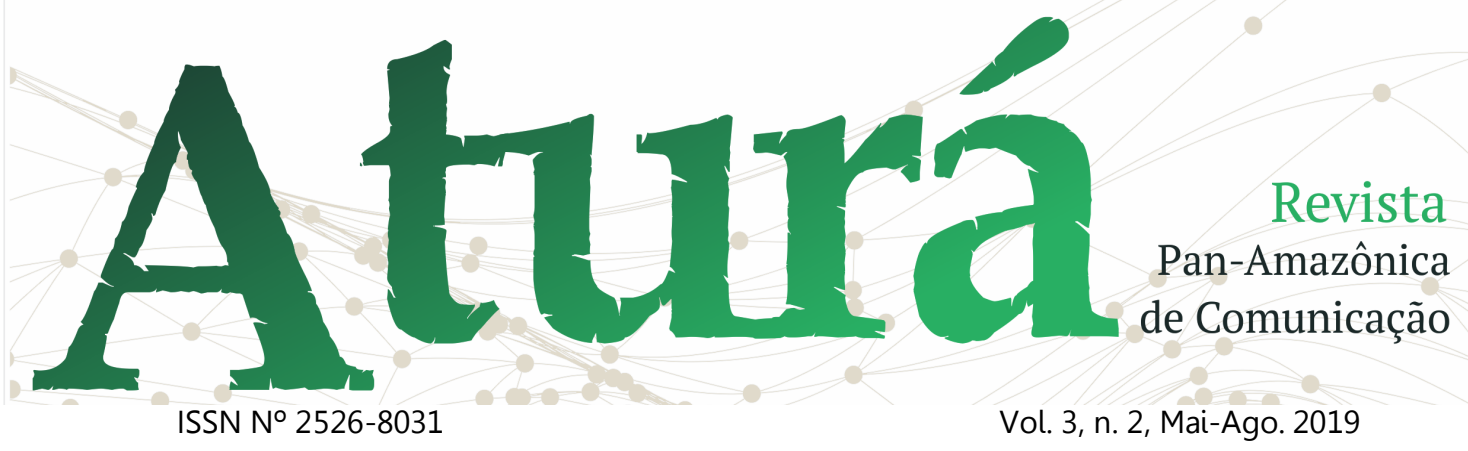

constrói. Os sentidos, por sua vez, são construídos e, depois, fixados social e culturalmente, por meio dos sistemas de representação.

Woodward (2012) considera que a diferença marca a identidade. Neste sentido, a raça pode ser tomada como um marcador de diferença, constituindo identidades. Conforme a autora, condições sociais e materiais também são constituintes das identidades, de modo que grupos simbolicamente marcados de forma negativa tendem a receber efeitos reais em suas vidas, sendo excluídos. A isso pode ser atribuída a situação dos negros no Brasil, tanto no que diz respeito ao impedimento da chegada desse grupo a determinados espaços simbólicos ou físicos quanto à naturalização da exclusão e fixação da ideia de que esse grupo só pode ocupar espaços subalternos ou desvalorizados socialmente.

Conforme Silva (2012), identidade e diferença nunca são inocentes, pois são relações sociais impostas e disputadas, não convivem em harmonia, já que envolvem diferentes grupos sociais situados de forma assimétrica em relação ao poder e disputam por outros recursos simbólicos e materiais. Para o autor, é a representação que liga a identidade e a diferença ao poder, já que "quem tem o poder de representar tem o poder de definir e determinar a identidade" (SILVA, 2012: p.91).

A diferença, para Woodward (2012), é o que afasta uma identidade da outra. Assim, sujeitos considerados diferentes de um grupo que tem mais poder são expostos a formas binárias de representação, tidos como extremos opostos em relação ao grupo hegemônico.

\section{Empoderamento social}

Segundo Berth (2018), empoderamento é uma fonte de transformação da estrutura racista - não como inversão, visando mudar o grupo que detém o poder, mas como uma "postura de enfrentamento da opressão para eliminação da situação injusta e equalização de existências em sociedade" (BERTH, 2018: p.16). Conforme a autora, o fenótipo da raça negra foi preterido, desde o período colonial, para que outro fosse valorizado. Isso fez negros se enxergarem de forma negativa e agressiva a partir da diferença em relação ao que é considerado padrão. Para enfrentar tal problemática, a autora (2018) afirma ser necessário que os negros façam mergulhos em si mesmos.

Uma coletividade empoderada é constituída por indivíduos que tenham "alto grau de recuperação da consciência do seu eu social, de suas implicações e agravantes" (BERTH, 2018: p.41), gerando 


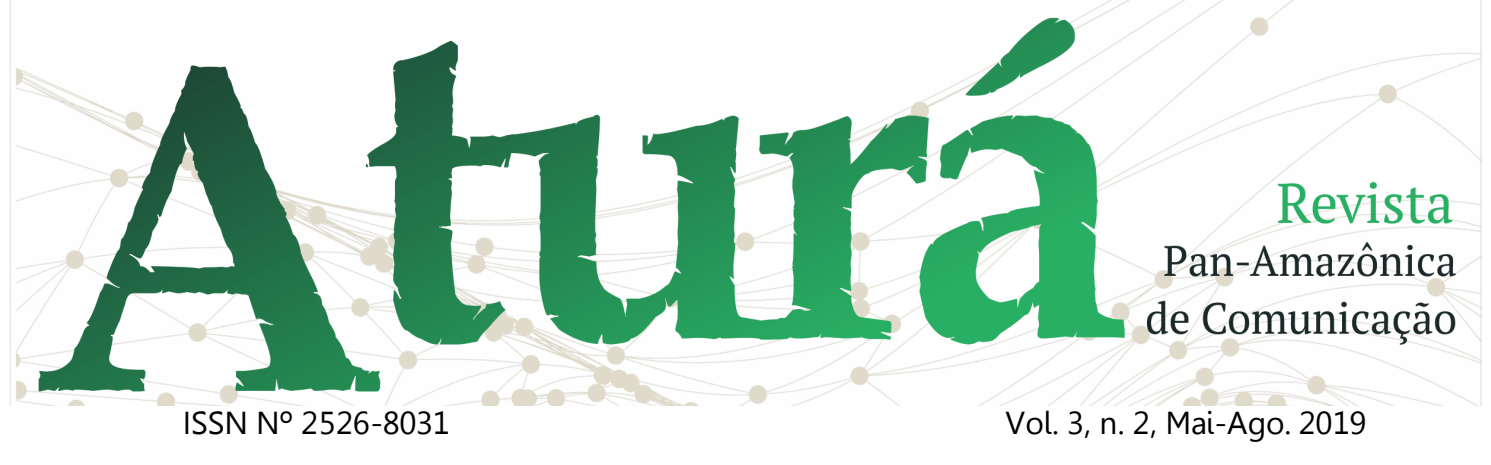

transformações que atingem a toda a sociedade. A autora defende que 0 empoderamento não tem como fim gerar uma relação de dependência de modo que um grupo sempre precise receber 0 poder de outro, mas é "um elemento de emancipação política e social" (BERTH, 2018: p.14).

\section{São Paulo Fashion Week. onde estão os negros?}

O SPFW deu seus primeiros passos em 1994. O evento tem duas edições por ano e acontece no parque Ibirapuera, na capital paulista. O desfile destinado a exibir peças primavera/verão acontece em março ou abril e o de outono/inverno em setembro ou outubro (KAETSU; VERDU, 2018).

Uma problemática que se destaca no São Paulo Fashion Week é a pequena quantidade de negros que passam por suas passarelas, o que fez com que 0 Ministério Público do Estado de São Paulo (MPSP) firmasse, no dia 20 de maio de 2009, um Termo de Ajustamento de Conduta (TAC) com a empresa Luminosidade Marketing \& Produções Ltda., responsável pela realização do SPFW. O TAC resultou de um inquérito civil instaurado pelo Grupo de Atuação Especial de Inclusão Social (GAEIS) do Ministério Público Estadual de São Paulo, em janeiro de 2008.
Segundo matéria divulgada pelo MPSP, por meio do acordo,

[...] a empresa se compromete a adotar uma série de providências para estimular a participação de modelos negros, afrodescendentes e indígenas no evento, como forma de promover a inclusão social no mundo da moda (MPSP, 2009: online).

Na prática, o SPFW deve expedir recomendação, no mínimo quinze dias antes do evento, a todos os estilistas que exibirão trabalhos, para que tenham em seus castings pelo menos $10 \%$ de modelos negros, afrodescendentes ou indígenas. Outro compromisso firmado no TAC é que deve ser feito ao MPSP o encaminhamento da comprovação de cumprimento das cláusulas e a relação dos modelos que desfilaram, por grife, discriminando quais se encaixam nos critérios determinados no acordo.

\section{Jornalismo: difusor de representações}

A análise das matérias feita neste trabalho baseia-se em cinco categorias: diversidade na $L A B$; contraponto: rua versus SPFW; ancestralidade, pertencimento e empoderamento na marca; a importância de contar sua própria história; e racismo no São Paulo Fashion Week: uma amostra do Brasil. Vale ressaltar que as categorias se subdividem em duas temáticas: as primeiras quatro categorias referem-se a pontos relacionados ao processo de 


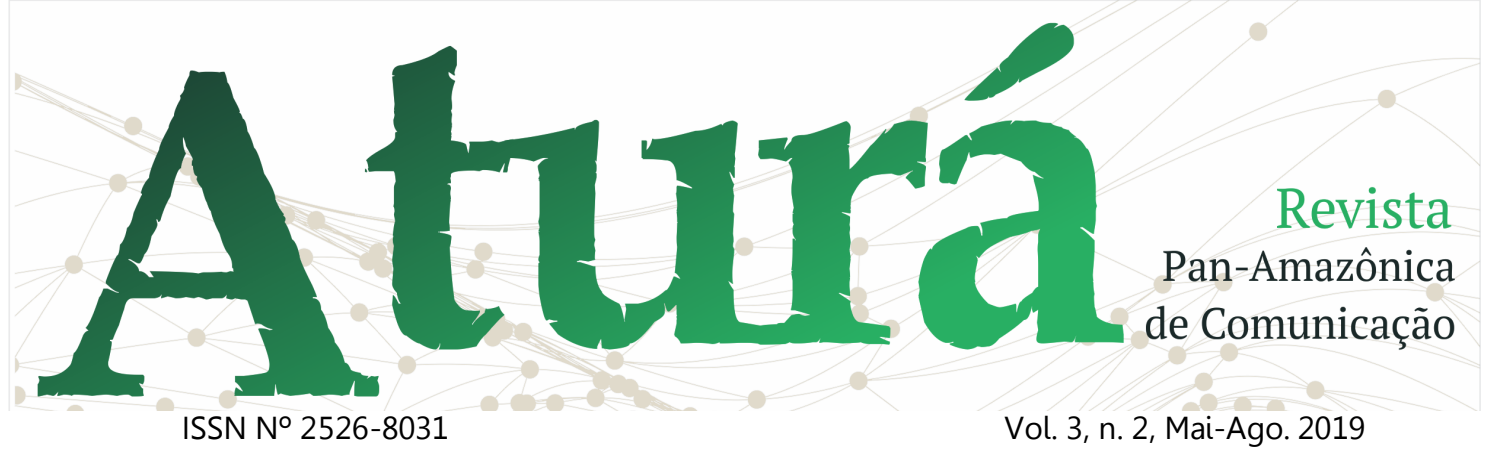

produção e aos desfiles da marca, enquanto a última diz respeito às matérias que têm como tema o episódio de racismo vivido por Fióti.

Os autores das matérias estudadas não pouparam elogios à marca realçando a diversidade apresentada por ela. A matéria intitulada $\angle A B$ injeta representatividade na passarela do SPFW, publicada no site da Vogue, tem como subtítulo:

Empreitada fashionista de Emicida com seu irmão Evandro Fióti foi destaque do segundo dia da semana de moda pelo casting e moda inclusivos (SANTOS, 2016: online.

Afirmações semelhantes a esta também podem ser percebidas em outros textos que apresentam um contraponto da proposta apresentada pela LAB em relação às outras marcas: "o Brasil, hoje, foi além: deu um show de diversidade tão honesto, tão genuíno, que o jogo se inverteu" (VASONE, 2016: online). Outra matéria colocou a LAB como mais subversiva do que a moda apresentada em outro momento histórico:

Os anos Dourados, a década de 1950, simbolizam o início de uma ruptura na estética linear da moda com o surgimento dos jovens transviados, as décadas seguintes promoveram incrementos gradativos no quesito diversidade, mas, de fato, nada comparado ao que temos visto em 2016: as então minorias estão subvertendo a ordem do dia e ganhando espaço e respeito nas passarelas elitistas. (VILAS BÔAS, 2016: online)

A partir da leitura desse trecho percebe-se que as passarelas do evento são compreendidas como um espaço de luta simbólica, onde as minorias estão se esforçando para chegar e conquistar respeito. Assim como Berth (2018), Nilma Lino Gomes (2003) considera o campo da estética importante para o enfrentamento dos problemas decorrentes da categorização de raças. Para a autora, o corpo carrega mensagens e, partindo de suas leituras, bem como da interpretação da forma como tal corpo é manipulado, é possível compreender a cultura negra.

Com a estreia da grife no evento, as matérias levantaram críticas ao sistema que privilegia brancos nas passarelas. A matéria Emicida: "Precisamos estourar a bolha e conversar sobre elegância", que se refere ao segundo desfile da $L A B$, ressalta que as pessoas estavam ansiosas para

[...] conferir o que a marca que sacudiu a moda brasileira há cinco meses, incitando debates como a falta de representatividade de corpos e de modelos negros, preparou para esta noite (LEVY, 2017: online).

Enquanto em Tudo o que você precisa saber sobre o último dia de SPFW é possível perceber a crítica aberta à norma do evento que tem na $L A B$ seu oposto:

[...] eles mantiveram o compromisso com um casting diverso e que ao contrário dos demais privilegiou modelos negros e 


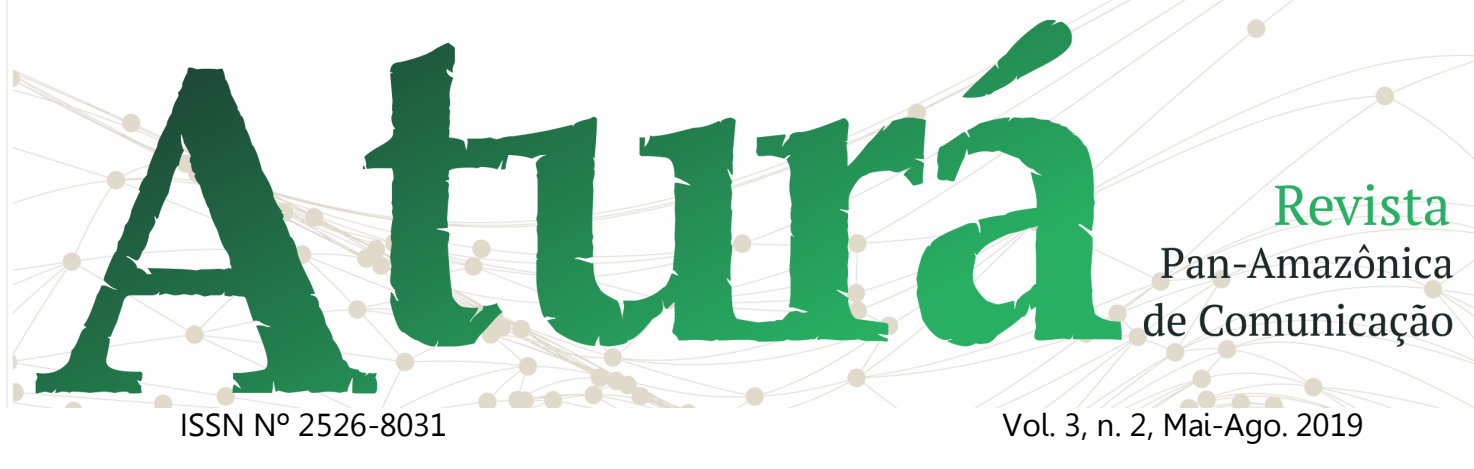

fechou com a trans Valentina Luz. (WHITEMAN, 2017: online).

Por fim, a matéria Emicida $e$ Evandro Fióti emocionam plateia com estreia de grife na SPFW destaca:

Felizmente, o desfile da $L A B$ em nada se parece com o que se vê na SPFW. Só pela seleção de modelões, $90 \%$ formada por negros e alguns do mercado plus size, a marca já se destaca (MESQUITA; DINIZ, 2016: online).

A existência de uma grife com um casting formado por uma minoria tornouse o ponto mais destacado nas matérias analisadas. Diante disso, o negro é posto como o ponto alto da grife:

O desfile apresentou opções para corpos de todos os tamanhos, opções que de fato estarão à venda. $O$ casting sobretudo negro não é cota, não foi feito para 'combinar' com o tema, não é exceção, é regra e verdade (WHITEMAN, 2016: online).

"A marca LAB tem o casting mais diverso do evento, colocando majoritariamente negros na passarela" (MESQUITA, 2017: online). Noutra passagem, o negro é citado como contraponto ao branco:

Precisou que um rapper invadisse a passarela para mostrar o óbvio: um desfile com a maioria de modelos negros é tão ou mais bonito do que um desfile de brancos escandinavos (VASONE, 2016: online).

Percebe-se, então, que o fato da marca levar negros às passarelas e construir novas representações sobre eles

gerou resultados positivos, afinal, existem outras leituras que se podem fazer desses sujeitos.

A segunda categoria abordada é a contraposição entre a vivência das ruas e - glamour que parece ser a aura do SPFW. É relevante, então, considerar as contribuições do antropólogo Roberto DaMatta, que apresenta uma discussão em que rua e casa são contrapostas e consideradas "dois espaços sociais fundamentais que dividem a sociedade brasileira" (DAMATTA, 1994: p.23). Partindo dessa contraposição, o autor classifica a casa como o local de calma, enquanto a rua é marcada por movimento, luta e perigo: "Na rua não há, teoricamente, nem amor, nem consideração, nem respeito, nem amizade" (DAMATTA, 1994: p.29).

A maioria das matérias analisadas faz alguma referência à relação de contraste entre rua e SPFW. Nos textos analisados, as palavras mais utilizadas para se referir ao que parece ser o oposto da semana de moda são: rua, calçada e favela: "De verdade, botando o streetwear no top da qualidade sem tirar o pé da rua, onde ele nasceu, cresceu e virou o que é" (WHITEMAN, 2016, online)

A estreia de sua marca e do irmão, o também rapper Evandro Fióti, é uma bemvinda injeção de rua em um evento que desconhecia a rima proposta pela dupla (MESQUITA; DINIZ, 2016: online). 


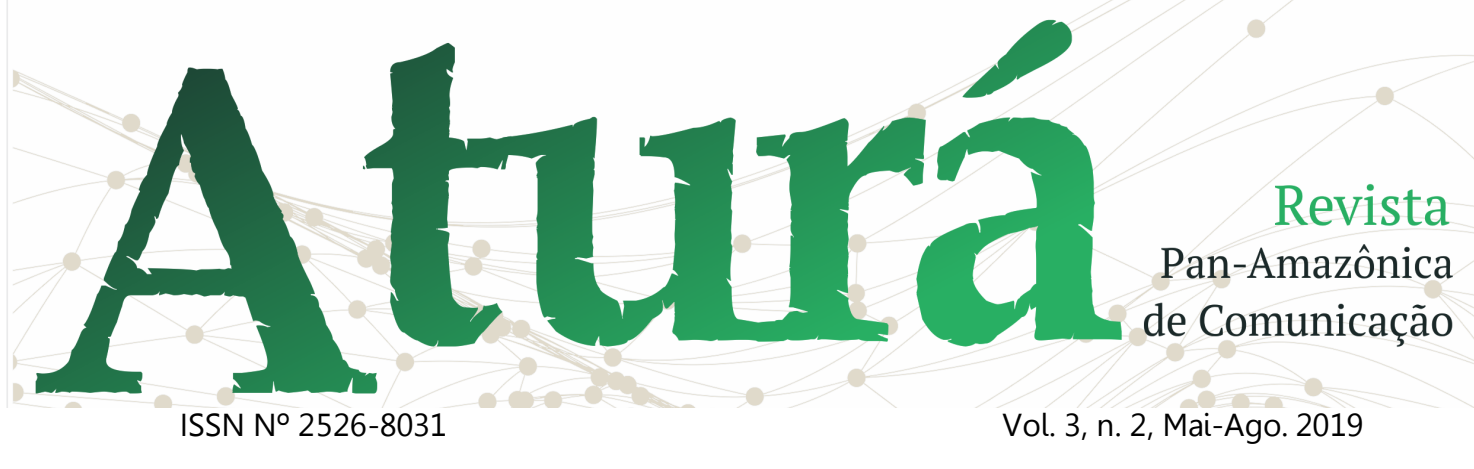

A coleção mistura códigos próprios da rua com outros do Japão, a exemplo das amarrações e das sobreposições (MESQUITA; DINIZ, 2016: online).

Essa espécie de dicotomia também pode ser notada nos títulos: $L a b$ colocou simplicidade da roupa da periferia na passarela da SPFW (MESQUITA, 2017: online); e 'SPFW pode estar próxima da favela', afirma Emicida (ROMBINO, 2016: online). As referências à favela e à periferia dialogam com as considerações de DaMatta (1994), pois esses espaços, assim como a rua, são considerados perigosos, ao contrário do SPFW.

É perceptível que a chegada da grife ao maior evento de moda da América Latina causou certo alvoroço. Diante disso, Eduardo Vilas Bôas tentou explicar tal repercussão na matéria Por que tanto barulho pela estreia da $\angle A B$ na SPFW?:

A $L A B$ fez barulho nas mídias sociais porque a rua finalmente se viu representada no templo do glamour e do luxo da moda. (VILAS BÔAS, 2016: online)

Em outras palavras, a chegada da marca ao evento é apresentada pela imprensa como um grande avanço, "símbolo de uma revolução que a moda tem vivido" (VILAS BÔAS, 2016: online). Contudo, vale ressaltar que a matéria não faz nenhum tipo de comentário destacando a rua enquanto espaço também político, constituído de sentido e relevância, independente de sua inserção nos desfiles de um palco de luxo como o do SPFW. Afinal, a rua em si é espaço dotado de significados, a própria cultura hip hop mostra isso.

O enfoque na simplicidade das roupas da $L A B$ dialoga com as ideias de Bergamo (2007, apud MARQUES, 2013), para quem escolhas de vestimentas e até mesmo sua existência não são por acaso. Numa perspectiva mais individualista ou grupal, a escolha da roupa é uma atitude

[...] perante a sociedade, ou, em outros termos, uma postura de coragem perante uma contingente posição social, capaz de suplantar a ordem social e sobre ela impor-se (BERGAMO, 2007, apud MARQUES, 2013: p.76).

Conforme Marques (2013), o autor apresenta o hip hop como exemplo dessa atitude de utilizar as vestimentas como um elemento que vai contra as estruturas sociais postas, de modo que determinada roupa precisa:
Necessariamente expressar, ou ser expressiva de uma postura de coragem perante a sociedade, configurando uma postura pessoal diante de uma ordem social que deve ser recusada (BERGAMO, 2007, apud MARQUES, 2013: p.76-77)
Em outros termos, o fato da LAB levar às passarelas roupas mais simples pode ser compreendido como resistência. 


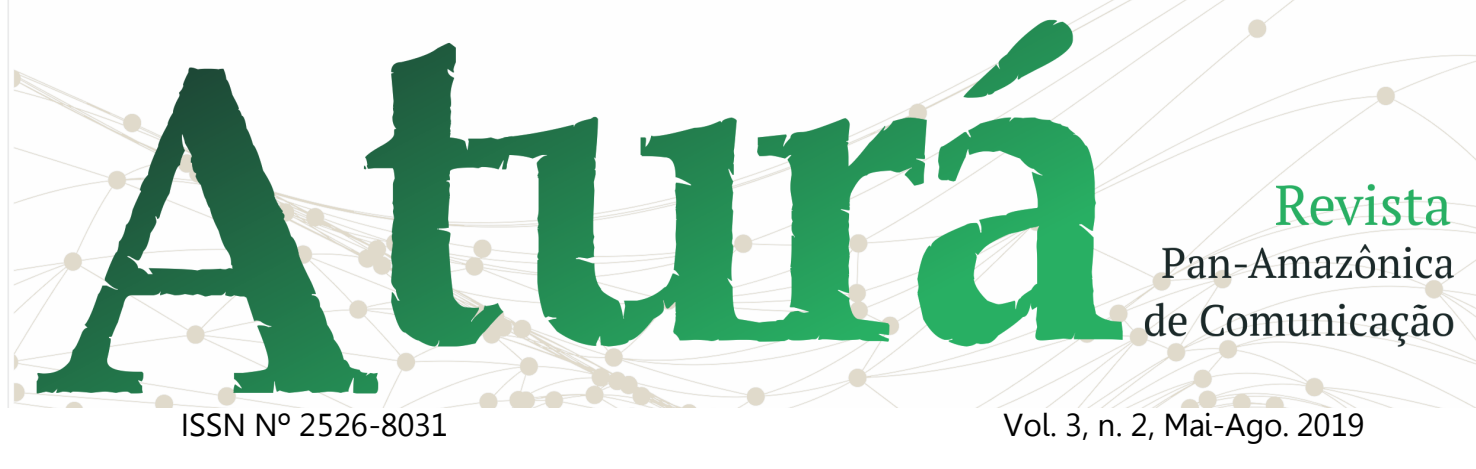

Ancestralidade, pertencimento e empoderamento na marca

Por ser uma marca pertencente a dois músicos negros de origem periférica e resultado de uma história construída por eles e por amigos, a grife é colocada nas matérias como detentora de um discurso que faz parte de sua essência. Neste sentido, mais uma vez a marca é situada em contraponto à maioria: "O discurso da diversidade, que para muitos é marketing, para eles é natural porque vem da raiz da história toda" (WHITEMAN, 2016: online). Sobre o primeiro desfile, Yasuke, dizia-se:

Não é mais uma estreia que tenta se aproveitar da periferia nem usar o hiphop como pano de fundo. Como diz uma letra do próprio Emicida, é pra "entender de nós, não só falar de nós" (WHITEMAN, 2016: online).

Neste trecho, nota-se que a autora coloca a LAB como dona de um discurso próprio à sua história, de algo que se conhece, se entende, se vive. Assim, cabe aqui relacionar tal colocação com o conceito de lugar de fala. Por meio da constituição de novos lugares de fala se possibilita visibilidade aos sujeitos considerados implícitos dentro de uma hegemonia:

O falar não se restringe ao ato de emitir palavras, mas de poder existir. Pensamos lugar de fala como refutar a historiografia tradicional e a hierarquização de saberes consequente da hierarquia social (RIBEIRO, 2017, p.66).
Para Djamila Ribeiro, os saberes e as epistemologias dos grupos subalternizados são invisibilizados, e, consequentemente, não têm reconhecimento, validação e valorização.

Considera-se que a chegada da LAB ao SPFW mostra que negros também possuem conhecimento, cultura e capacidade de produzir música, moda e empreendedorismo. O reconhecimento dessa capacidade fica evidente nos trechos a seguir, no qual a autora destaca a importância de abrir espaço ao protagonismo de Emicida e Fióti:

É sempre interessante notar o quanto a
mudança de sujeito faz diferença. O
samba e a herança africana já foram
temas de inúmeras coleções. Nesta,
porém, o ponto de vista é outro, mais
próximo, de fato vivido, o que se reflete
nas roupas (WHITEMAN, 2017: online).

Outro aspecto que se destaca nas matérias é a referência feita à importância da ancestralidade. Para compreender a ancestralidade africana é importante conhecer o significado de arkhé. Conforme Muniz Sodré (1988, apud PETIT; CRUZ, 2008), o termo refere-se às culturas cuja fundação e recriação estão ligadas às vivências e reconhecimento da ancestralidade, concebida não apenas como origem, mas também como um

[...] eterno impulso inaugural da força de continuidade do grupo. A arkhé está no passado e no futuro, é tanto origem como destino. (SODRÉ, 1988, apud PETIT; CRUZ, 2008: p.2). 


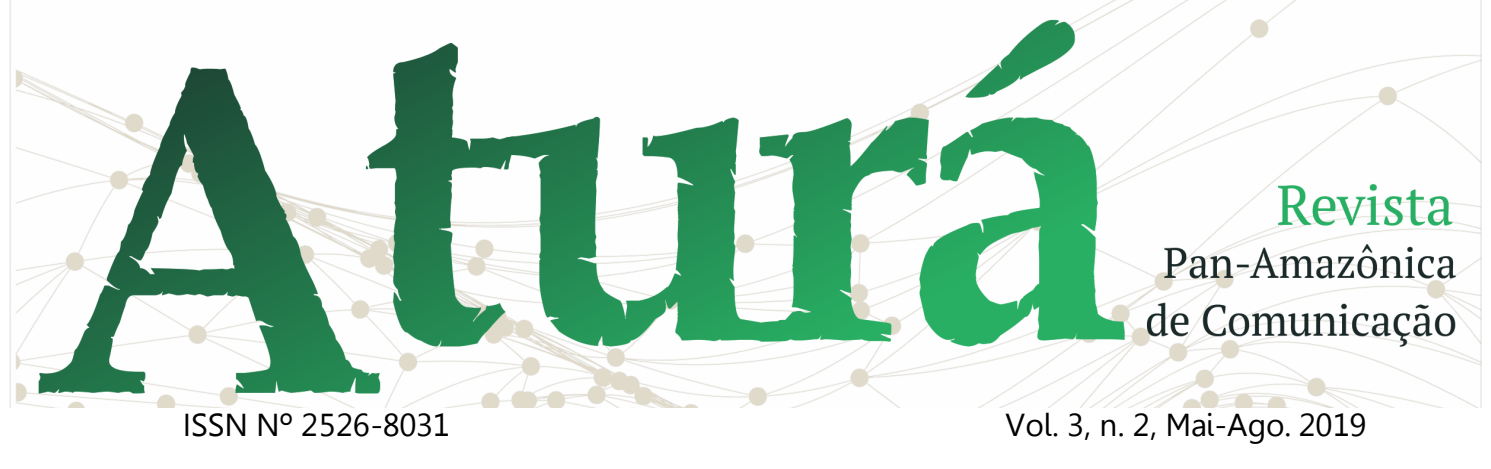

Essa noção de ancestralidade pode ser percebida no primeiro desfile, quando a trilha sonora foi "uma mistura de macumba e música japonesa cantada por um coro de velhinhas" (DINIZ, 2016: online). Para Sandra Petit e Norval Cruz (2008),

A ancestralidade também é a inserção numa comunidade e o sentimento de pertencimento alimentado pela capacidade de traçar a genealogia e contar as histórias do coletivo (PETIT; CRUZ, 2008: p.3).

Considerando a LAB como um catalisador de debates que raramente chegam ao SPFW, referindo-se ao segundo desfile da marca, uma das matérias diz: "falar de raízes em um país como o Brasil é afrontar um presente bastante racista e desafiar noções arraigadas de beleza" (LEVY, 2017: online). No mesmo texto se afirma não haver nada

[...] mais inteligente do que se voltar aos que os fortaleceram no passado, como grupo e como indivíduos, para afrontar com fôlego um hoje desafiador. (LEVY, 2017: online)

Essa afirmação dialoga com a ideia de ancestralidade apresentada no parágrafo anterior, referindo-se ao conceito como fonte de força para a existência de um grupo.

Já o conceito de empoderamento pode ser percebido no trecho:

$O$ desfile foi um caso à parte, Emicida cantando "as pessoas são como as palavras, só têm sentido juntas" é um

recado forte. Não o da conciliação boba, submissa, mas o de quem chega com espírito de somar, mas também de mudar as regras, de causar movimento (WHITEMAN, 2016: online).

O último período da citação mostra que a chegada da marca não carrega inocência ou uma conciliação sem sentido, sem objetivo de mudar estruturas, características entendidas por Berth (2018) como intrínsecas ao empoderamento. A autora considera ser necessário que o sistema e o modelo de negócios seja desenvolvido por negros, focando nesse público e gerando retorno para ele, de modo a possibilitar a restauração de sua humanidade e beneficiá-lo inclusive com os lucros.

\section{A importância de contar sua própria história}

Dentre as 18 matérias focadas na marca, 10 trazem falas dos donos, em forma de entrevistas transcritas e em falas pronunciadas durante os desfiles. Nelas se percebe a repetição das temáticas dos temas citados no tópico anterior. A matéria '"SPFW pode estar próxima da favela', afirma Emicida" traz uma entrevista com o rapper.

$O$ que representa para um rapper fazer parte da SPFW? Quando o Emicida e o Fióti saem de onde saíram, constroem uma história como a da Laboratório e conseguem ter relevância ao ponto de circular ao lado de outras marcas no maior evento de moda da América Latina, estamos dizendo para as pessoas que têm 


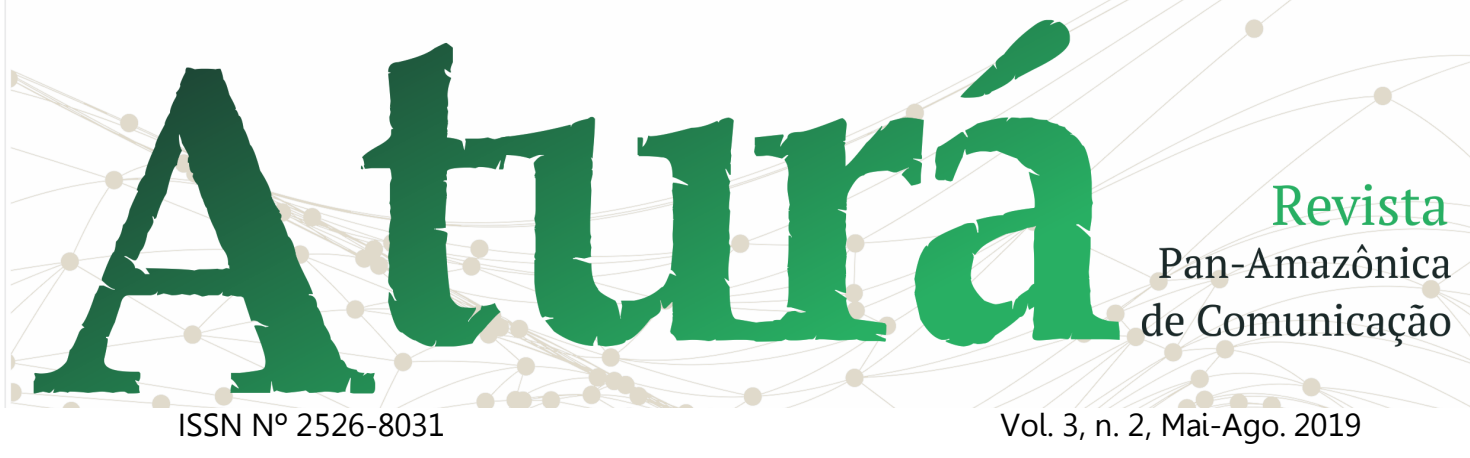

a nossa origem que tudo é possível. Gostaria muito de aproximar realidades diferentes: a São Paulo Fashion Week pode ser mais próxima da favela, e as favelas mais próximas da São Paulo Fashion Week. O Brasil é um caldeirão de criatividade e a gente perde muito por não ter a vazão necessária (ALONSO; ROMBINO, 2016: online).

Percebe-se na visão de Emicida uma noção de empoderamento, pois a partir dele e de Fióti, enquanto idealizadores de uma marca nascida na periferia como uma opção de sobrevivência, pode haver uma influência positiva na vida de outras pessoas vindas da mesma origem, aqui compreendida tanto social quanto economicamente. Nota-se também a queixa do artista sobre a falta de "vazão necessária". Compreende-se a partir dessa colocação que existem grupos sub-representados ou não representados nesse ambiente de criação, o São Paulo Fashion Week, o que acaba impedindo uma expressão mais diversa do Brasil, da mistura de culturas e diferenças existentes no país.

Referindo-se à compreensão da relevância da chegada da $L A B$ à maior semana de moda da América Latina, Fióti diz: "A gente quer mostrar um Brasil pouco ou nunca visto dentro dessa estrutura da semana de moda" (SANTOS, 2016: online).

Nota-se na fala do músico uma preocupação com a mudança de pensamentos - entendida como a derrubada de preconceitos limitadores das capacidades dos negros - e de posturas - mudança nas práticas regentes da indústria fashion. É importante relembrar que tais pensamentos e posturas foram forjados e naturalizados historicamente ao longo de séculos e, por isso, são necessários esforços para concretizar alterações. Um exemplo da materialização de mudança de postura é a equiparação da presença de negros em posição de destaque no SPFW em relação aos brancos, realidade ainda não alcançada.

Para Emicida, o desfile Yasuke é "uma releitura da 'ancestralidade africana que se perdeu no Brasil'" (DINIZ, 2016: online). No mesmo texto, o rapper destaca o Brasil é como um país onde "há mais pretos fora da África e mais asiáticos fora da Ásia" e conclui: "Estamos então ressignificando nossa história". Tal colocação faz sentido vista sob o manto da cultura enquanto um produto vivo, em constante modificação e, no caso da marca, sempre trazendo evidências da ancestralidade africana. Também é possível perceber esta temática nas matérias que dão atenção à fala de Dona Jacira, considerada como um ponto chave na coleção Herança:

Ao falar sobre o samba tem que ter o devido respeito, então resolvi fazer isso contando uma história, como um mito, porque eu não tenho autoridade de pesquisadora (MARÇAL, 2017: online). 


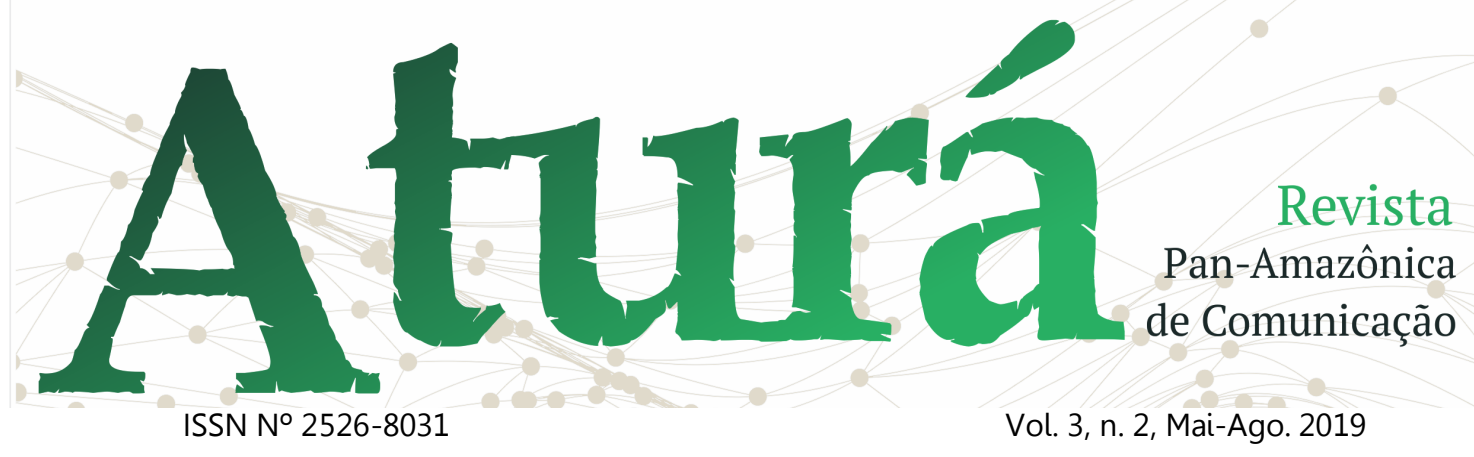

Fica evidente mais uma vez a relação com o conceito de lugar de fala, já que Dona Jacira faz uso de outra epistemologia e reconhece a diferença entre falar tendo "autoridade de pesquisadora" e falar "contando uma história, como um mito". Isso não significa superioridade de uma forma de produção de saber em relação à outra, significa apenas que são diferentes lugares de fala.

\section{Racismo no São Paulo Fashion Week. uma amostra do Brasil}

A última categoria é focada no episódio de racismo vivido por Fióti no último dia de participação da $\angle A B$ no SPFW. De acordo com as matérias analisadas, Fióti foi impedido de entrar em determinada área do evento, mesmo estando com a credencial adequada para acessá-la. $O$ ato de impedir alguém de fazer algo em função da cor de sua pele caracteriza racismo, conforme a Lei Afonso Arinos, de 1951 (SCHWARCZ, 2012).

As matérias tratam o caso como racismo:

Após o evento, o músico Evandro Fióti, fundador da marca ao lado do irmão, o rapper Emicida, foi vítima de racismo nos corredores da Fundação Bienal (ROMBINO, 2017: online).

Aparentemente distante das passarelas desde o último protesto por mais modelos negros na São Paulo Fashion Week, em 2013, o racismo e os

questionamentos sobre apropriação cultural foram temas que voltaram à Bienal do Ibirapuera nesta quinta (31). (DINIZ; MESQUITA, 2017: online).

Nomear o ocorrido como racismo é importante, pois, a partir do reconhecimento da existência do problema, ele é tratado como amplo e histórico, e não apenas como uma situação isolada.

Um ponto relevante das matérias é o espaço dado à fala de Fióti sobre o ocorrido. Vale ressaltar que, conforme vídeo divulgado na página do São Paulo Fashion Week no Facebook, Fióti preferiu não dar entrevistas sobre a situação, para evitar que as matérias identificassem o evento como racista, sem fazer uma abordagem mais profunda do problema. A partir disso, compreende-se que todas as matérias aqui analisadas foram escritas com base na fala de Fióti disponível no vídeo.

O que se defende nos textos de modo geral é que o cantor ressalta a característica estrutural do racismo, como defende Almeida (2018). Esse posicionamento do artista fica evidente no texto Fióti sobre caso de racismo: 'Não é exclusivo da SPFW, é uma questão estrutural' (ALMEIDA, 2017: online). A fala de Fióti corrobora com esse ponto de vista: "A gente vive em um país racista e o evento acontece neste país" (ALMEIDA, 2017: online). 


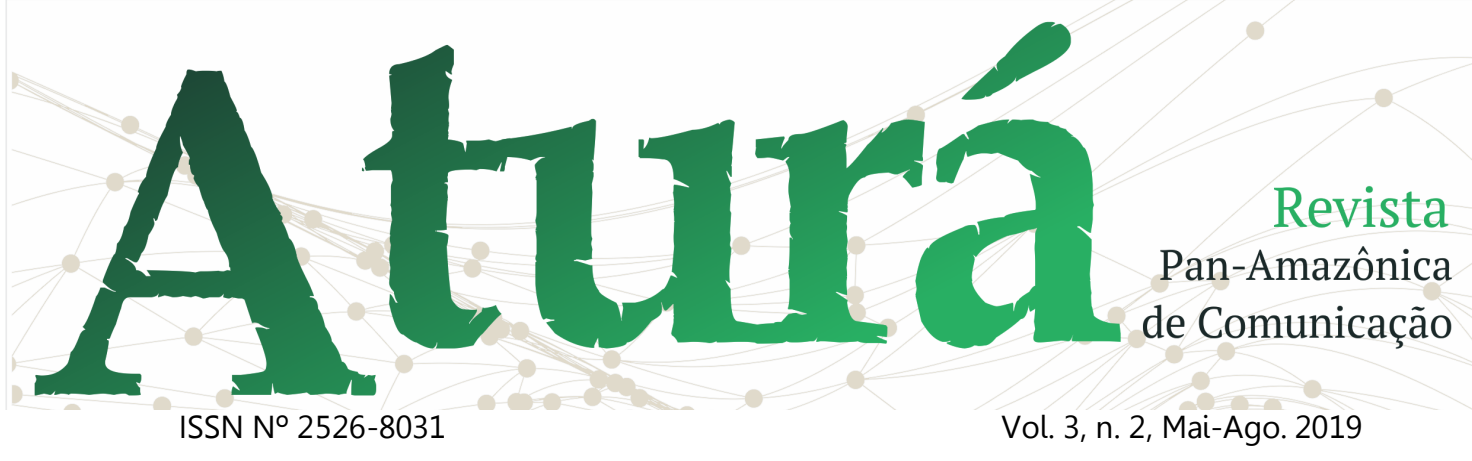

Outro ponto importante é o fato de tanto Fióti quanto Paulo Borges, idealizador do São Paulo Fashion Week, terem entendimento do racismo enquanto problema não resolvível apenas com punição. Fióti

[...] ainda pediu para que os funcionários sejam direcionados a 'tratar os seres humanos sem exclusão'. Paulo Borges ainda reforçou: "A questão não é a punição, é a educação" (ALMEIDA, 2017: online).

Para Almeida (2018), a responsabilização e punição jurídica não são capazes de gerar mudança na capacidade de reprodução de desigualdade racial. Um problema sistemático não pode ser resolvido com ações isoladas, nem com punições individuais.

Em outro texto, argumenta-se que, embora as marcas tenham defendido o discurso a favor da diversidade nos desfiles e na frente das câmeras, nos bastidores do evento a mesma história de sempre se repetia. $O$ autor da matéria, Pedro Diniz, relaciona o fato ocorrido com o dono da LAB ao Termo de Ajustamento de Conduta firmado entre 0 SPFW e o Ministério Público de São Paulo em 2009, para mostrar que as mudanças não foram tão significativas.

Percebe-se que, se de um lado a melhor forma de lidar com ocorrido para Fióti foi gravar um vídeo relatando, problematizando a situação e deixando

evidente sua indignação, ao invés de ceder entrevistas aos jornalistas e correr o risco de ter suas falas distorcidas, do outro, o organizador do evento, Paulo Borges, focou na perspectiva estrutural do racismo, frisando que o SPFW é apenas mais um espaço onde ocorre a reprodução do fenômeno.

\section{Considerações finais}

O corpus formado por 23 matérias de veículos que tratam da temática moda - os sites Estadão, Folha de São Paulo, Elle e Vogue - confirmou que a chegada da grife $L A B$ ao maior evento de moda da América Latina não apenas gerou discussão, mas fez com que importantes veículos de jornalismo nacionais levantassem críticas à situação do negro em um espaço de destaque positivo como o São Paulo Fashion Week.

A partir da análise das matérias é possível perceber que a entrada de uma grife que exalta corpos negros e fora de alguns padrões no SPFW é celebrada. Porém, o racismo veio à tona após o último dia de desfiles da $L A B$, confirmando a existência do racismo à la brasileira. Nos textos sobre os desfiles, a presença do negro é exaltada, enquanto nas estruturas sociais há uma repulsa a esses corpos.

No que se refere à fala de Fióti sobre o racismo estrutural, vale fazer uma ressalva sobre os veículos Elle e Vogue: 


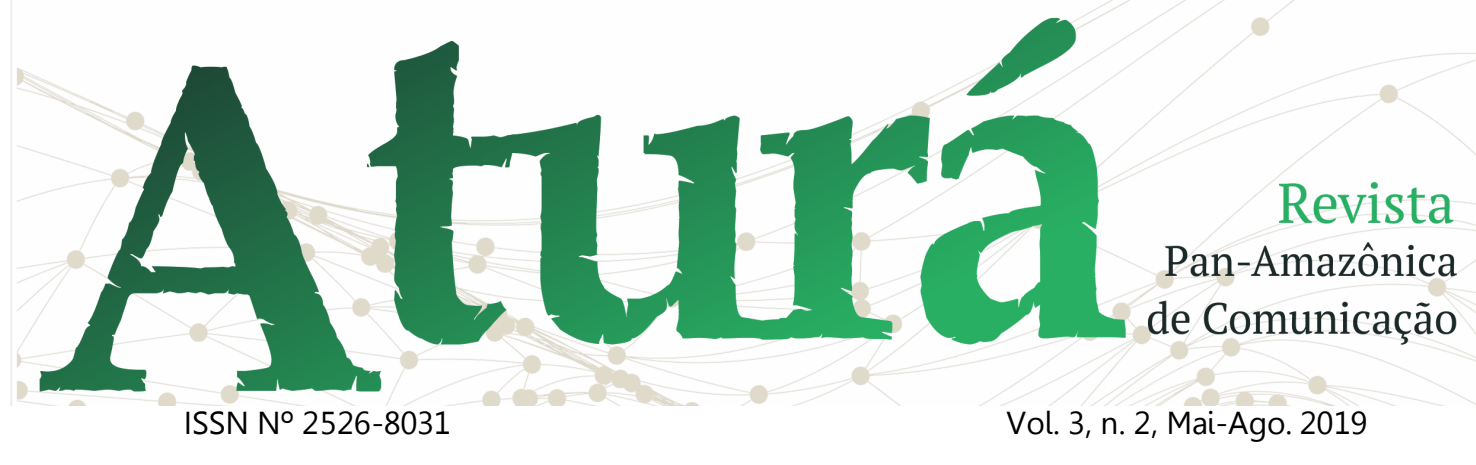

não adianta escrever matérias que enaltecem 0 fenótipo dos negros se quando ocorre um ato de discriminação contra um deles não se problematiza e debate $o$ assunto.

As representações que julgam os donos da LAB como inovadores, detentores de um discurso próprio, representantes da diversidade racial brasileira etc não têm utilidade nenhuma se construídas de modo isolado de outras narrativas problematizadoras do racismo e de outros tipos de opressão.

É necessário dialogar sobre essas questões, por mais problemáticas e dolorosas que sejam. Caso contrário, não há nenhum tipo de reflexão, nem mudança. Parafraseando Djamila Ribeiro (2018), para perceber o racismo existente não precisa ler Frantz Fanon, basta observar as passarelas e os bastidores do São Paulo Fashion Week.

\section{Referências}

ALMEIDA, Isadora de. Fióti sobre caso de racismo: 'Não é exclusivo da SPFW, é uma questão estrutural'. Estadão, 01 set. 2017. Disponível em: <http://twixar.me/psZ1>. Acesso em: 02 fev. 2019.

ALMEIDA, Silvio Luiz de. O que é racismo estrutural? Belo Horizonte (MG): Letramento, 2018.

ALONSO, Maria Rita; ALMEIDA, Isadora de. Emicida faz trilha ao vivo com Fióti, Rael e outros rappers na SPFW. Estadão, 29 ago.
$2017 . \quad$ Disponível em: $<$ http://twixar.me/tsZ1>. Acesso em: 02 fev. 2019.

ALONSO, Maria Rita; ROMBINO, Anna. A emocionante estreia de Emicida na SPFW. Estadão, 24 out. 2016. Disponível em: $<$ http://twixar.me/8sZ1>. Acesso em: 02 fev. 2019.

BARDIN, Laurence. Análise de conteúdo. Lisboa: Edições 70, 1977.

BERTH, Joice. O que é empoderamento? Belo Horizonte (MG): Letramento, 2018.

DAMATTA, Roberto. O que faz o brasil, Brasil?. Rio de Janeiro: Editora Rocco, 1994.

DINIZ, Pedro. Emicida embala 'macumba' e cultura japonesa em desfile da SPFW. Folha de S. Paulo, 24 out. 2016. Disponível em: <http://twixar.me/RsZ1>. Acesso em: 02 fev. 2019.

DINIZ, Pedro; MESQUITA, Giuliana. Em temporada que preconiza a diversidade, segurança barra dono de marca negro e estilista mostra África europeizada. Folha de S. Paulo, 01 set. 2017. Disponível em: <http://twixar.me/PsZ1>. Acesso em: 02 fev. 2019.

DINIZ, Pedro. SPFW expôs como o discurso pró-diversidade pode ser vazio. Folha de $\mathbf{S}$. Paulo, 01 set. 2017. Disponível em: <http://twixar.me/7sZ1>. Acesso em: 02 fev. 2019.

GARGARO, Larissa. LAB resgata as origens do samba em seu inverno 2017. Vogue, 17 mar. $2017 . \quad$ Disponível em: <http://twixar.me/MsZ1>. Acesso em: 02 fev. 2019. 


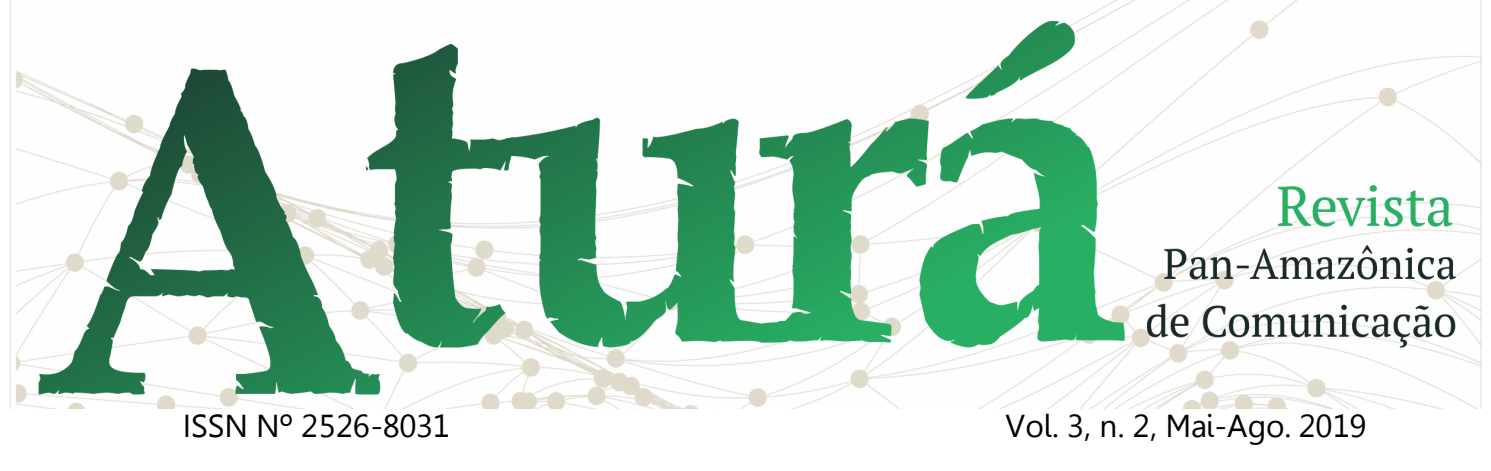

GOMES, Nilma Lino. Revista Brasileira de Educação. Universidade Federal de Minas Gerais, Faculdade de Educação. Maio-Ago 2003, n.23. p.75-85 Disponível em: <http://twixar.me/QsZ1>. Acesso em: 15 abr. 2019.

HALL, Stuart. Cultura e representação. Tradução: Daniel Miranda e William Oliveira. Rio de Janeiro: PUC-Rio: Apicuri, 2016.

IBGE - Instituto Brasileiro de Geografia e Estatística. Censo Demográfico 2010: Características gerais da população, religião e pessoas com deficiência. Disponível em: <http://twixar.me/WMh1>. Acesso em: 15 out. 2018.

IBGE - Instituto Brasileiro de Geografia e Estatística. Indicadores IBGE: pesquisa nacional por amostra de domicílios contínua. Disponível em: <http://twixar.me/fMh1>. Acesso em: 15 out. 2018.

KAETSU, Suzie Terci; VERDU, Fabiane Cortez. A transnacionalização da moda brasileira: da via de mão única para a via de mão dupla. Disponível em: <http://twixar.me/dMh1>. Anais do $14^{\circ}$ Colóquio de Moda. Acesso em: 23 jan. 2018.

KELLNER, Douglas. A cultura da mídia estudos culturais: identidade e política entre o moderno e o pós-moderno. Bauru, SP: EDUSC, 2001.

MARÇAL, Gabriela. Bordados feitos pela mãe de Emicida serão destaque da LAb na SPFW. Estadão, 17 mar. 2017. Disponível em: <http://twixar.me/qsZ1>. Acesso em: $02 \mathrm{fev}$. 2019.
MARQUES, Camila da Silva. É rap! É roupa! Moda hip-hop: iguais e diferentes. 2013. Dissertação (Mestrado em Comunicação) Universidade Federal de Santa Maria, Santa Maria, 2013.

MESQUITA, Giuliana. Após acusação de racismo, SPFW chama Fióti para gravar vídeo sobre hipocrisia. Folha de S. Paulo, 31 ago. $2017 . \quad$ Disponível em: <http://twixar.me/nMZ1>. Acesso em: 02 fev. 2019.

MESQUITA, Giuliana; DINIZ, Pedro. Emicida e Evandro Fióti emocionam plateia com estreia de grife na SPFW. Folha de S. Paulo, 24 out. 2016. Disponível em: <http://twixar.me/fMZ1>. Acesso em: 02 fev. 2019.

MESQUITA, Giuliana. Evandro Fióti, da LAB, diz ter sofrido discriminação por seguranças da SPFW. Folha de S. Paulo, 31 ago. 2017. Disponivel em: <http://twixar.me/1MZ1>. Acesso em: 02 fev. 2019.

MESQUITA, Giuliana. Lab colocou simplicidade da roupa da periferia na passarela da SPFW. Folha de S. Paulo, 29 ago. $2017 . \quad$ Disponível em: <http://twixar.me/3MZ1>. Acesso em: $02 \mathrm{fev}$. 2019.

MINISTÉRIO PÚBLICO DE SÃO PAULO. SP Fashion Week e MP firmam TAC para incentivar inclusão social de negros nos desfiles. 20 maio. 2009. Disponível em: <http://twixar.me/TMZ1> Acesso: 24 jan. 2019.

MUNANGA, Kabengele. Uma abordagem conceitual das noções de raça, racismo, identidade e etnia. In: Seminário Nacional 


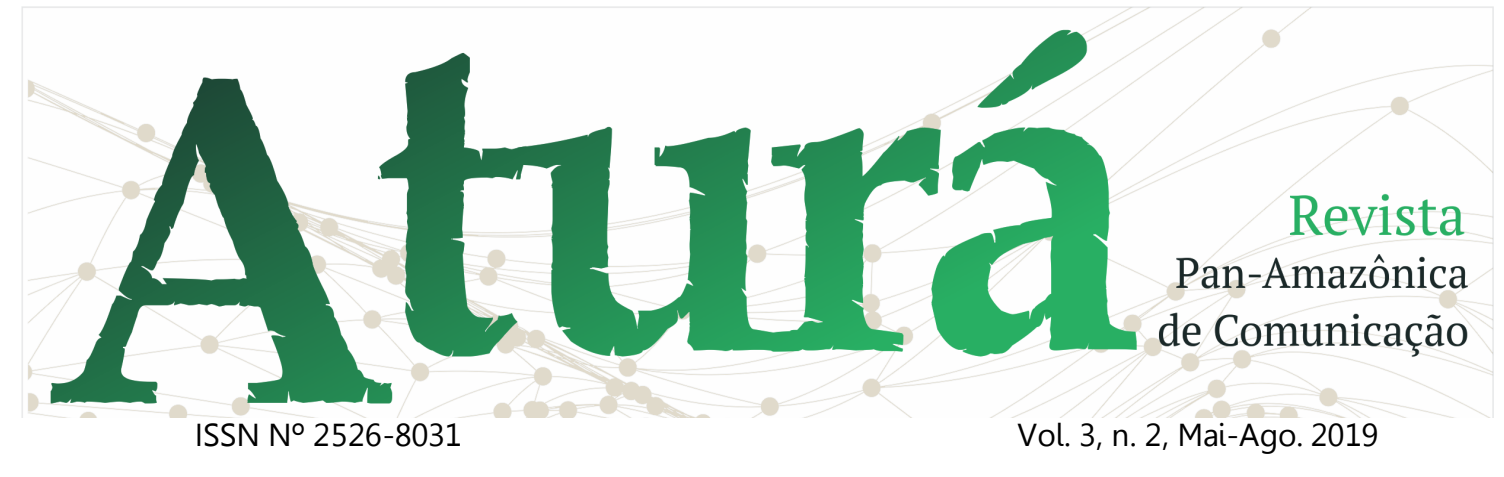

Relações Raciais E Educação - PENESB. Rio de Janeiro, 2003. Anais. Rio de Janeiro, 2003. Disponível em: <http://twixar.me/mMZ1>. Acesso em: 20 dez. 2018.

PADILHA, Camila. LAB alça voo no verão. Vogue, 29 ago. 2019. Disponível em: <http://twixar.me/GMZ1>. Acesso em: 02 fev. 2019.

Página do São Paulo Fashion Week no Facebook. Confira o esclarecedor bate papo entre Paulo Borges e Fióti. \#SPFW. São Paulo Fashion Week, 31 ago. 2017. Disponível em: <http://twixar.me/dMZ1>. Acesso em: 21 abr. 2019.

PETIT, Sandra Haydée; CRUZ, Norval Batista. Arkhé: corpo, simbologia e ancestralidade como canais de ensinamento na educação. In: Anais da $31^{\text {a }}$ Reunião anual da Associação Nacional de Pós-graduação e Pesquisa em Educação, p.1-13, 2008. Disponível em: <http://twixar.me/0MZ1>. Acesso em: 19 abr. 2019.

RIBEIRO, Djamila. O que: é lugar de fala? Belo Horizonte (MG): Letramento: Justificando, 2017.

RIBEIRO, Djamila. Quem tem medo do feminismo negro? - São Paulo: Companhia das Letras, 2018.

ROMBINO, Anna. LAB na SPFW: deu samba. Estadão, 17 mar. 2017. Disponível em: <http://twixar.me/LMZ1>. Acesso em: 02 fev. 2019.

ROMBINO, Anna. 'Ser preto é ser barrado no evento da sua marca', diz Fióti, dono da $L A B$, sobre ocorrido na SPFW. Estadão, 31 ago. 2017.
<http://twixar.me/WMZ1>. Acesso em: 02 fev. 2019.

ROMBINO, Anna. 'SPFW pode estar próxima da favela', afirma Emicida. Estadão, 21 out. $2016 . \quad$ Disponível em: <http://twixar.me/vMZ1>. Acesso em: 02 fev. 2019.

SANTOS, Guga. LAB injeta representatividade na passarela do SPFW. Vogue, 24 out. 2016. Disponível em: <http://twixar.me/4MZ1>. Acesso em: 02 fev. 2019.

SCHWARCZ, Lilia Moritz. Nem preto nem branco, muito pelo contrário. Cor e raça na sociabilidade brasileira. São Paulo: Claro Enigma, 2012.

SILVA, Tomaz Tadeu da (Org). Identidade e diferença: a perspectiva dos estudos culturais. Petrópolis, RJ: Vozes, 2012.

VILAS BÔAS, Eduardo. Por que tanto barulho pela estreia da LAB na SPFW? Folha de S. Paulo, 26 out. 2016. Disponível em: <http://twixar.me/gMZ1>. Acesso em: $02 \mathrm{fev}$. 2019. 